\title{
RELATIONSHIP BETWEEN HONEYBEE (APIS MELLIFERA L.) COLONY WEIGHTS AND SOME ACTIVITIES
}

\author{
Naglaa E. Ghazala, A. A.Taha and Amany S.M. AbouLila \\ Beekeeping Research Department, Plant Protection Research Institute, \\ Agricultural Research Center, Egypt.
}

Received: Feb. 11, 2017

Accepted: Mar. 1, 2017

\begin{abstract}
This work was conducted in the apiary of Plant Protection Research Institute at El Quanater, Qaliobia Governorate to study the relationship between weight (in $\mathrm{kg}$ )of honeybee colonies (Apis mellifera L.) and some activities, i.e. worker sealed brood area (inch ${ }^{2}$ ), stored pollen area and stored honey yields through the period from 1/03/2016 to 5/06/2016. The more weight colonies produced more areas of stored pollen, worker sealed brood, and honey yield compared with the less weight colonies. Results revealed that there are positive significant correlation between weight of honeybee colonies and activities. The increase in weight of colonies means the increase in stored pollen area, this lead to the increase in brood and honey yields, producing healthy and strong colonies. This research confirms that the weight of the colonies is the most important indicator to measure the activities of honey bee colonies.
\end{abstract}

Key words: Honey bees, Weight, pollen, honey, sealed brood.

\section{INTRODUCTION}

After continuous weight loss through winter, with occasional rainfall spikes, hives started to gain weight in March and continued to do so into May. Honeybee colony weight was related to honey stored. Honey stored was shown to be dependent on the number of days from the beginning of the honey harvest. The weight colony data is a measure of hive activity and food demand. Weight colony data can also be used to detect the acute loss of foragers. continuous hive weight data can be used to calculate the rate of food consumption (McLellan, 1977).Weekly changes in running average weights, were correlated with food store changes, hive weight changes indicate the beginning and end of the nectar flow, identify when the honey supers are full, identify when winter feeding is required, indicate swarming and robbing event, and changes in colony strength and productivity (William et al., 2008). Weighing hives daily or weekly is done by beekeepers and bee researchers (Szabo and Lefkovitch, 1991; Harbo, 1993; Kenyon, 1898 and Savary, 2006) to help determine the best time to harvest honey or estimate food reserves for periods with nectar flow. Weighing is fast, requires little training and is not disruptive to the colony so it can be done at any time of year. Weighing hives regularly, often, and with relatively high precision can provide useful information on colony dynamics (Buchmann and Thoenes, 1990) and (ELKazafy et al., 2013). First proposed using high-precision electronic balances, fit sine curves to the de trended data, hive weight data gathered over 17 months to explore the relationship of the sine curve parameters to information on colony growth and activity. Weight data collected continuously were summarized and compared to hive inspection data gathered about every 2 weeks by (Meikle et al., 2006). Continuous hive weight data can be used to calculate the rate of food consumption, while continuous temperature data indicate energy expenditure as well as the location of the bee mass,( William and Milagra, 2014). Honey and pollen quantities, notably honey production, are the factors most correlated with colony weight (Lecocq et al., 2015). Hive weight track weight gain over time, map the start and finish of the nectar flow, identify when honey boxes are full, compare hive 
productivity. Monitor winter store levels and identify if the bees need feeding, (Meikle and Holst, 2015).

This work was conducted to study the relationship between weight (in $\mathrm{kg}$ ) of honeybee colonies (Apis mellifera L.) and some activities, i.e. worker sealed brood area, stored pollen area and stored honey yields through the period from $1 / 03 / 2016$ to 5/06/2016.

\section{MATERIALS AND METHODS}

The experiment was carried out under the Apiary conditions at the of Plant Protection Research Institute in Qunater, Qaliobia governorate during the period from $1 / 3$ to $5 / 06 / 2016$. The worker brood areas a standard frame divided to square inches were used. Brood, pollen and honey areas were measured every 12 days until the first of June, 2016. The first inspection of brood was taken just before the beginning of the experiment on $1 / 3 / 2016$.

\section{1- Honey bee strains and numbers:}

The strength colony contains at least eight standard frames covering with bees. These colonies were headed with equal queen ages. Twelve honey bee F1 Carniolan colonies were selected. The colonies have been divided into 4 groups (A, $B, C$ and $D$ groups) each of 3 colonies about equal brood areas, pollen and honey areas.

\section{2- Estimating worker sealed brood areas, stored pollen and stored honey areas:}

To measure the inches of worker sealed brood, stored pollen and stored honey areas the frame in standard frame was used according to (Omar, 1998 and Al-Tickrity et al., 1971). Brood, pollen and honey areas were measured every 12 days according to the equation of (Shoreit and Hussein, 1993).

\section{3- Estimating colonies weight:}

The colonies were each placed on top of stainless steel electronic balances every twelve days during estimating the biological data. The balances had a maximum capacity of $100 \mathrm{~kg}$, a precision of $\pm 30 \mathrm{~g}$ described by (Meikle et al., 2006). Hives were weight without bees or feeders and then colonies (hive+ bees+ feeder) were weight every twelve days the first of March 2016 to 5/06/2016.

\section{4- Statistical analysis:}

Obtained data were statistically analyzed; the correlation coefficient values between the studies of weight colonies and some their activities from sealed brood, pollen stored and honey yield stored were recorded using SAS program (1999). Duncan multiple range test was used to compare the means between the groups.

\section{RESULTS AND DISSCUSSION Relationship between weight honeybee colonies and worker sealed brood:}

The obtained results in Table (1) show that the highest colony weights in all groups (A , B, C and D ) were $(26.00,24.25,32.23$ and $19.00 \mathrm{~kg} \mathrm{/} \mathrm{colony,} \mathrm{respectively)} \mathrm{at}$ $5 / 6 / 2016$, raised to $(25.50,23.50,31.42$ and $18.87 \mathrm{~kg} /$ colony ) at $24 / 5 / 2016$ in the tested groups respectively .

The highest sealed brood areas as a result of rearing activity were (610.11, $650.11,690.90$ and $598.65 \mathrm{inch}^{2} /$ colony, respectively ) in the groups (A. B, C, and D) at $5 / 6 / 2016$ while the values of the sealed brood areas at 24/5/2016 were decreased (531.33, 570.21, $\quad 610.70$ and 492.11 inch $^{2} /$ colony, respectively ) in groups before extracting the clover honey.

Analysis of the obtained data revealed significant correlation coefficient $r$ values among weight colonies and worker sealed brood areas in A, B, C and D as it recorded $r=0.902,0.832,0.715$ and 0.856 , respectively. Measurements of sealed brood areas in combs were used to estimate the strong colonies of honey bees. 
Table (1). Relationship between average weight of honeybee colonies by $/ \mathrm{kg}$, and average sealed brood areas / inche ${ }^{2}$ during 2016 season.

\begin{tabular}{|c|c|c|c|c|c|c|c|c|}
\hline \multirow{3}{*}{$\begin{array}{l}\text { Date } \\
\text { at } 12 \text { days } \\
\text { intervals }\end{array}$} & \multicolumn{8}{|c|}{ Average of sealed brood area $/$ inch $^{2}$} \\
\hline & \multicolumn{2}{|c|}{ A } & \multicolumn{2}{|c|}{ B } & \multicolumn{2}{|c|}{ C } & \multicolumn{2}{|c|}{$\mathrm{D}$} \\
\hline & W & Sb & W & $\mathrm{Sb}$ & W & Sb & W & Sb \\
\hline $01 / 03 / 2016$ & $12.18 \mathrm{C}$ & $128.60 \mathrm{D}$ & $15.85 \mathrm{~B}$ & $234.50 \mathrm{~B}$ & $19.00 \mathrm{~A}$ & $246.16 A$ & $12.00 \mathrm{C}$ & $125.80 \mathrm{C}$ \\
\hline $13 / 03 / 2016$ & $14.15 \mathrm{C}$ & $298.70 A$ & $16.20 \mathrm{~B}$ & $265.61 \mathrm{C}$ & $20.32 \mathrm{~A}$ & 276.12B & 13.10D & 210.14D \\
\hline $25 / 03 / 2016$ & 15. $83 \mathrm{C}$ & $303.00 \mathrm{~B}$ & $17.50 \mathrm{~B}$ & $291.00 \mathrm{C}$ & $22.52 \mathrm{~A}$ & 317.33A & $14.40 \mathrm{C}$ & 263.66D \\
\hline 06/04/2016 & 18.17B & $416.00 \mathrm{~B}$ & 18.33B & $386.00 \mathrm{C}$ & $19.58 \mathrm{~A}$ & 443.67A & $16.00 \mathrm{C}$ & 374.67D \\
\hline $18 / 04 / 2016$ & 18. $83 \mathrm{D}$ & $465.33 C$ & 19.17BC & 513.34B & $21.33 \mathrm{~A}$ & $440.00 \mathrm{~A}$ & 17.91D & $389.12 \mathrm{D}$ \\
\hline $30 / 04 / 2016$ & $21.17 \mathrm{~A}$ & $433.33 \mathrm{~A}$ & $21.00 \mathrm{~A}$ & $450.00 \mathrm{~B}$ & $22.17 \mathrm{~A}$ & 462.66C & 19.58B & 415.00D \\
\hline $12 / 05 / 2016$ & $21.08 \mathrm{~B}$ & 495.62D & $20.08 \mathrm{~B}$ & $510.33 C$ & $21.75 \mathrm{~A}$ & $570.23 A$ & $18.25 \mathrm{C}$ & 478.32E \\
\hline $24 / 05 / 2016$ & $25.50 \mathrm{~B}$ & $531.33 \mathrm{C}$ & $23.50 \mathrm{C}$ & $570.21 \mathrm{~B}$ & $31.42 \mathrm{~A}$ & $610.70 \mathrm{~A}$ & 18.87D & 492.11D \\
\hline 05/06/2016 & $26.00 \mathrm{~B}$ & $610.11 \mathrm{C}$ & $24.25 B$ & $650.11 \mathrm{~B}$ & $32.23 \mathrm{~A}$ & $690.90 \mathrm{~A}$ & 19.00D & 598.65D \\
\hline Correlation & \multicolumn{2}{|c|}{0.902} & \multicolumn{2}{|c|}{0.832} & \multicolumn{2}{|c|}{0.715} & \multicolumn{2}{|c|}{0.856} \\
\hline
\end{tabular}

$\mathrm{W}=$ Weight by/colony $(\mathrm{kg},) \mathrm{Sb}=$ Sealed brood $/$ colony inch ${ }^{2}$

Means within each column or row followed by the same letter/s didn't significantly differ at $5 \%$ level.

\section{Relationship between weight of honeybee colonies and pollen areas:}

The obtained results in Table (2) show the average values of pollen area per inch $^{2}$ at each honeybee group colonies, the statistical analysis of the data revealed significant correlation coefficient $r$ values among weight colonies and pollen stored areas in A, B, C and D groups as it recorded $r=0.952, \quad 0.820,0.747$ and 0.836 , respectively.

The highest pollen area values in the tested groups (A, B, C and D) were correlated with the weights of (26.00, $24.25,32.23$ and $19.00 \mathrm{~kg} \mathrm{/} \mathrm{colony,}$ respectively) at 5/6/2016 then in all groups the colony weights were $(25.50,23.50$, 31.42 and $18.87 \mathrm{~kg} /$ colony, respectively ) at the date of $24 / 5 / 2016$.

The best pollen stored areas as a result of honeybee activity were $(364.54,360.23$, 390.11 and 275.33 inch $^{2} /$ colony), in groups
$(\mathrm{A}, \mathrm{B}, \mathrm{C}$ and $\mathrm{D})$ respectively when examined at the date of $5 / 6 / 2016$, while the pollen stored areas activity were $(360.520,359.04$, 389.45 and 262.30 inch $^{2}$ / colony), in groups $(A, B, C$ and $D)$ respectively when calculated at the date of $24 / 5 / 2016$.

The measurements of stored pollen areas in combs were used to estimate the activity of pollen storage of honey bees.

\section{Relationship between weight of honeybee colonies and honey stored areas: \\ The obtained results in Table (3)} indicated that the best date for $5 / 6$ and $24 / 5$ /2016 in all groups in stored honey areas $(A, B, C$ and $D)$ in weight colonies were (26.00, 24.25, 32.23 and $19.00 \mathrm{~kg} /$ colony) in $5 / 6 / 2016$, respectively and $(25.50,23.50$, 31.42 and18.87 kg/colony ) in 24/5/2016. The best honey stored areas activity (450.65, 399.89, 478.87 and 375.33 inch $^{2} /$ colony), respectively in groups (A. B, C and 
Ghazala, et al.,

$D$ in $5 / 6 / 2016$ then $(397.50,389.60$, 477.90 and $362.30 \mathrm{inch}^{2} /$ colony) in 24/5/2016 before extracting the clover honey. Analysis of data revealed significant correlation coefficient $r$ values among weight colonies and honey stored areas in $\mathrm{A}, \mathrm{B}, \mathrm{C}$ and $\mathrm{D}$ as it recorded $\mathrm{r}=0.902$, $0.851,0.570$ and 0.935 respectively.

Table (2): Relationship between average weight of honeybee colonies (kg), and average pollen stored areas/ inch ${ }^{2}$ during 2016 season.

\begin{tabular}{|c|c|c|c|c|c|c|c|c|}
\hline \multirow{2}{*}{\begin{tabular}{c} 
Date $\begin{array}{c}\text { at 12 days } \\
\text { intervals }\end{array}$ \\
\cline { 2 - 9 }
\end{tabular}} & \multicolumn{2}{|c|}{ A } & \multicolumn{2}{c|}{ B } & \multicolumn{2}{c|}{ C } & \multicolumn{2}{c|}{ D } \\
\cline { 2 - 9 } & W & PS & W & PS & W & PS & W & PS \\
\hline $01 / 03 / 2016$ & $12.18 \mathrm{C}$ & $100.10 \mathrm{D}$ & $15.85 \mathrm{~B}$ & $150.23 \mathrm{C}$ & $19.00 \mathrm{~A}$ & $271.00 \mathrm{~B}$ & $12.00 \mathrm{C}$ & $97.32 \mathrm{E}$ \\
\hline $13 / 03 / 2016$ & $14.15 \mathrm{C}$ & $120.32 \mathrm{C}$ & $16.20 \mathrm{~B}$ & $180.70 \mathrm{~B}$ & $20.32 \mathrm{~A}$ & $345.10 \mathrm{~A}$ & $13.10 \mathrm{D}$ & $103.12 \mathrm{D}$ \\
\hline $25 / 03 / 2016$ & $15.83 \mathrm{C}$ & $146.40 \mathrm{D}$ & $17.50 \mathrm{~B}$ & $236.33 \mathrm{C}$ & $22.52 \mathrm{~A}$ & $355.33 \mathrm{~B}$ & $14.00 \mathrm{C}$ & $110.67 \mathrm{E}$ \\
\hline $06 / 04 / 2016$ & $18.17 \mathrm{~B}$ & $250.67 \mathrm{D}$ & $18.33 \mathrm{~B}$ & $263.33 \mathrm{C}$ & $18.58 \mathrm{~A}$ & $286.33 \mathrm{~A}$ & $16.00 \mathrm{C}$ & $123.33 \mathrm{E}$ \\
\hline $18 / 04 / 2016$ & $18.83 \mathrm{CD}$ & $255.33 \mathrm{D}$ & $19.17 \mathrm{~B}$ & $269.0 \mathrm{C}$ & $21.33 \mathrm{~A}$ & $352.80 \mathrm{~A}$ & $17.91 \mathrm{D}$ & $248.3 \mathrm{E}$ \\
\hline $30 / 04 / 2016$ & $21.17 \mathrm{~A}$ & $295.00 \mathrm{D}$ & $21.00 \mathrm{~A}$ & $356.67 \mathrm{~B}$ & $22.17 \mathrm{~A}$ & $359.33 \mathrm{~A}$ & $19.58 \mathrm{~B}$ & $287.00 \mathrm{E}$ \\
\hline $12 / 05 / 2016$ & $21.08 \mathrm{AB}$ & $305.42 \mathrm{C}$ & $20.08 \mathrm{~B}$ & $302.00 \mathrm{D}$ & $21.75 \mathrm{~A}$ & $357.32 \mathrm{~B}$ & $18.25 \mathrm{C}$ & $250.54 \mathrm{E}$ \\
\hline $24 / 05 / 2016$ & $25.50 \mathrm{~B}$ & $360.20 \mathrm{~B}$ & $23.50 \mathrm{C}$ & $359.04 \mathrm{C}$ & $31.42 \mathrm{~A}$ & $389.45 \mathrm{~A}$ & $18.87 \mathrm{D}$ & $275.33 \mathrm{D}$ \\
\hline $05 / 06 / 2016$ & $26.00 \mathrm{~B}$ & $364.54 \mathrm{~B}$ & $24.25 \mathrm{~B}$ & $360.23 \mathrm{C}$ & $32.23 \mathrm{~A}$ & $390.11 \mathrm{~A}$ & $19.00 \mathrm{D}$ & $262.30 \mathrm{D}$ \\
\hline Correlation & \multicolumn{2}{|c|}{$\mathbf{0 . 9 5 2}$} & \multicolumn{2}{|c|}{$\mathbf{0 . 8 2}$} & \multicolumn{6}{c|}{$\mathbf{0 . 7 4 7}$} & $\mathbf{0 . 8 3 6}$ \\
\hline
\end{tabular}

$\mathrm{W}=$ Weight /colony $\left(\mathrm{kg}\right.$, ) Ps $=$ Stored Pollen / colony inch ${ }^{2}$

Means within each column or row followed by the same letter/s didn't significantly differ at $5 \%$ level.

Table (3): Relationship between average weight colonies/kg and average honey stored areas/inch ${ }^{2}$ during 2016 year.

\begin{tabular}{|c|c|c|c|c|c|c|c|c|}
\hline \multirow{3}{*}{$\begin{array}{l}\text { Date } \\
\text { at } 12 \text { days } \\
\text { intervals }\end{array}$} & \multicolumn{8}{|c|}{ Average of stored honey areas/inch ${ }^{2}$} \\
\hline & \multicolumn{2}{|c|}{ A } & \multicolumn{2}{|c|}{ B } & \multicolumn{2}{|c|}{ C } & \multicolumn{2}{|r|}{ D } \\
\hline & W & $\mathrm{H}$ & W & $\mathrm{H}$ & W & $\mathrm{H}$ & W & $\mathrm{H}$ \\
\hline $01 / 03 / 2016$ & $12.18 \mathrm{C}$ & 107.40D & 15.85B & $154.25 \mathrm{C}$ & $19.00 \mathrm{~A}$ & $313.65 \mathrm{~A}$ & $12.00 \mathrm{~B}$ & 111.10D \\
\hline $13 / 03 / 2016$ & $14.15 \mathrm{~A}$ & 156.33D & 16.20B & $175.90 \mathrm{C}$ & $20.32 \mathrm{~A}$ & $380.20 \mathrm{~A}$ & $13.10 \mathrm{C}$ & 146.20D \\
\hline $25 / 03 / 2016$ & $1583 C$ & 167.67D & $17.50 \mathrm{~B}$ & $178.00 \mathrm{C}$ & $22.52 \mathrm{~A}$ & 392.67A & $14.40 \mathrm{C}$ & 152.33E \\
\hline 06/04/2016 & 18.17B & 295.67B & 18.33B & $253.00 \mathrm{D}$ & $19.58 \mathrm{~A}$ & $377.00 \mathrm{~A}$ & $16.00 \mathrm{C}$ & 240.33E \\
\hline $18 / 04 / 2016$ & $1883 B$ & $351.35 \mathrm{C}$ & 19.17B & $354.67 \mathrm{~B}$ & $21.33 \mathrm{~A}$ & 537.67A & $17.91 \mathrm{C}$ & 245.44E \\
\hline $30 / 04 / 2016$ & $21.17 \mathrm{~A}$ & 251.67D & $21.00 \mathrm{~A}$ & 247.33D & $22.17 \mathrm{~A}$ & $426.00 \mathrm{~A}$ & 19.58B & 324.67B \\
\hline $12 / 05 / 2016$ & $21.08 \mathrm{~A}$ & 250.20E & $20.08 \mathrm{~B}$ & 376.50B & $21.75 \mathrm{~A}$ & $419.90 \mathrm{~A}$ & $18.25 \mathrm{C}$ & 259.54D \\
\hline $24 / 05 / 2016$ & $25.50 \mathrm{~B}$ & $397.50 \mathrm{C}$ & $24.25 \mathrm{C}$ & 399.89B & $31.42 \mathrm{~A}$ & 478.87A & $19.00 \mathrm{E}$ & 375.33D \\
\hline 05/06/2016 & $26.00 \mathrm{~B}$ & 450.65B & $23.50 \mathrm{C}$ & $389.60 \mathrm{C}$ & $32.23 \mathrm{~A}$ & $477.90 \mathrm{~A}$ & 18.87E & 362.30E \\
\hline Correlation & \multicolumn{2}{|c|}{0.902} & \multicolumn{2}{|c|}{0.851} & \multicolumn{2}{|c|}{0.570} & \multicolumn{2}{|c|}{0.935} \\
\hline
\end{tabular}

$\mathrm{W}=$ Weight by/colony $(\mathrm{kg},) \mathrm{H}=$ Honey stored by/ colony $\left(\right.$ inch $\left.^{2}\right)$.

Means within each column or row followed by the same letter/s didn't significantly differ at $5 \%$ level. 
Finally, from the obtained Data in Tables $(1,2$ and 3$)$, it could be concluded that the colony weight is sharply increased from the beginning of March, as well as the weight of honeybee colonies as a good indicator for the honeybee activities, where by increasing colony weight, honeybee activities will be the highest.

The obtained results are in agreement with those of (Meikle et al., 2008), who mentioned that, weekly changes in running average weights were correlated with food store, furthermore, weight data such as those presented could provide a more complete picture of hive dynamics, as well as weighing hives regularly, often, and with relatively high precision can provide useful information on colony dynamics. Buchmann and Thoenes (1990) reported that when the colony weight stop increasing gave the time of extracting the honey.

\section{REFERANCES}

Al-Tickrity, W.S., R.C. Hillmann, A.W. Benton and W.W. Clarke (1971). A new instrument for brood measurement in a honey bee colony. Amer. Bee J., 111 (4): 143-145.

Buchmann, S.L. and S.C. Thoenes (1990). The electronic scale honey bee colony as a management and research tool. Bee Sci., 1: 40-47

EL-Kazafy, A. Taha and Saad Naser AlKahtani (2013). Relationship between Population Size and Productivity of Honey Bee Colonies. Journal of Entomology, 10: 163-169.

Harbo, J.R. (1993). Worker-bee crowding affects brood production, honey production and longevity of honey bees (Hymenoptera: Apidae). J. Econ. Entomol., 86: 1672-1678.

Kenyon, F. C. (1898). The Daily and Seasonal Activity of a Hive of Bees. The American Naturalist Vol. 32, No. 374 , pp. 90-95.

Lecocq, A., P. Kryger, F. Vejsnæs and Bruun Jensen A. (2015). Weight Watching and the Effect of Landscape on Honeybee Colony Productivity: Investigating the Value of Colony Weight
Monitoring for the Beekeeping Industry. PLoS ONE 10(7): e0132473. doi:10.1371/journal.pone. 0132473

McLellan A.R. (1977). Honey bee colony weight as an index of honey production and nectar flow: a criticalevaluation, J. Appl. Ecol. 14, 401-408.

Meikle, W.G., N. Holst, G. Mercadier, F. Derouané and R.R. James (2006). Using balances linked to dataloggers to monitor honey bee colonies. J. Apic. Res., 45: 39-41.

Meikle, W.G., B.G. Rector, G. Mercadier and N. Holst (2008). Within-day variation in continuous hive weight data as a measure of honey bee colony activity. Apidologie, 39: 694-707

Meikle, W.G. and N. Holst (2015). Application of continuous monitoring of honeybee colonies. Apidologie, Volume 46, pp 10-22.

Omar, R. E. (1998). Studies on some honey bee races in Egypt. Ph.D. Thesis, Fac. of Agric., Moshtohor, Zagazig Univ.

SAS (1999). Statistical Analysis System, SAS / STAT User's Guide. Release 6.03 Ed. SAS Institute, Cary,NC, 1028 p.

Shoriet, M. N. and M. N. Hussein (1993). Field tests with some protein supplements for feeding bees at Assuit Governorate. Egypt. J. Appl. Sci., 8: 366375.

Savary, F. (2006). Le conservatoire de l'abeille noire provençale. Bull. Tech. Apic., 32:115

Szabo, T.I. and L.P. Lefkovitch (1991). Effects of honey removal and supering on honey bee colony gain, Am. Bee J. 131, 120-122.

William, G. Meikle, Brian G. Rector, Guy Mercadier and Niels Holst (2008). Withinday variation in continuous hive weight data as a measure of honey bee colony. Apidologie 39, $694-707$.

William Meikle and Milagra Weiss (2014). What do continuous weight and temperature monitoring tell us about honey bee colony status and activity? Conference: Entomological Society of America Annual Meeting. 


\section{العلاقة بين وزن طوائف نحل العسل ويعض أنشطتها}

\section{نجلاء الاحمدى غزالة ، عمرو أحمد طه ، أمانى سعد مصطفى أبو ليلة}

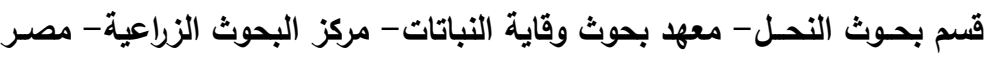

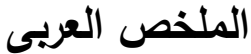

أجرى هذا البحث بفرع بحوث النحل بالقناطر الخيرية التابع لمعهد بحوث وقاية النباتات بهدف دراسة العلاقة بين وزن طوائف نحل العسل بالكيلو جرام وبعض أنشطتها من حيث قياس مساحة كلا من الحضنة المقفولة والعل لبل وحبوب اللقاح بالبوصة المربعة خلال الفترة من 2016/3/1 حتى 2016/6/5. أوضحت النتائج أن طوائف نحل العسل الاعلى فى الوزن هى الاعلى فى معدل انتاجية مساحات الحضنة المقفولة و العسل و حبوب اللقاح عن الطوائف الاقل وزنا. وأنشارت النتائج أيضا الى وجود ارتباط قوى بين وزن طوائف نحل العسل و بعض أنشطتها وهذا يوضح ان زيادة وزن الطوائف يرجع الى نوافر حبوب اللقاح المخزنة وبالتالى زيادة الحضنة و العسل مما يدل على قوة هذه الطوائف. والخلاصة يؤكد هذا البحث ان وزن الطوائف هو من اهم طرق قياس أنشطة طوئف نحل 